\title{
DELAYED HYPERSENSITIVITY IN SYSTEMIC LUPUS ERYTHEMATOSUS*
}

\author{
BY \\ SIDNEY R. BLOCK†, CHARLES B. GIBBS, MARY BETTY STEVENS, \\ AND LAWRENCE E. SHULMAN \\ From The Connective Tissue Division, Department of Medicine, School of Medicine, \\ The Johns Hopkins Hospital, Baltimore, Maryland
}

Systemic lupus erythematosus (SLE) is a disorder of unusual immunological reactivity in which abnormalities of both humoural and delayed-type hypersensitivity are found. Most characteristic of the disease are the multiple circulating antibodies, especially antinuclear factors, which have the capacity to react with autologous cellular antigens. However, the relationship of these serum autoantibodies to the tissue manifestation of the disease remains obscure.

Holman (1960) and Friedman, Bardawil, Merrill, and Hanau (1960) described a tuberculin-like response to the intradermal injection of autologous and homologous leucocytes in patients with SLE and, less frequently, rheumatoid arthritis. Subsequent workers (Tromovitch and March, 1961 ; Bennett and Holley, 1961; Azoury, Jones, Derbes, and Gum, 1966) have confirmed this cutaneous hypersensitivity to leucocytes in the majority of patients with SLE; furthermore, a similar dermal response has been demonstrated after challenge with heterologous nuclear antigens, especially calf thymus deoxyribonucleic acid (DNA) (Azoury and others, 1966; Ores and Lange, 1964; Chieregato and Faldarini, 1964; Fardal and Winkelmann, 1965). Whether this delayed-typed reaction indicates altered cellular hypersensitivity only to nuclear constituents or reflects a more generalized hyperergic state is not known. It is even possible that the cutaneous response to leucocyte and nuclear antigens results from a local interaction between antigen and circulating antinuclear antibody, although the temporal sequence is not that of classical Arthustype reactivity.

The present study was undertaken to investigate these possibilities. Patients with systemic lupus

* This work was supported by an Arthritis Foundation Clinical Study Center Grant, and in part by a U.S. Public Service Clinical Research Grant (5 MO 1 FR 35 27)

$\uparrow$ Cornell New York Hospital Medical Center, New York, N.Y. erythematosus or with rheumatoid arthritis and controls were challenged with a battery of bacterial and fungal antigens and calf thymus DNA. No evidence for heightened delayed hypersensitivity in patients with SLE was found, even with respect to DNA. In fact, patients with systemic lupus demonstrated a significant hyporeactivity to intermediate strength PPD (purified protein derivative (tuberculin)) which, although unexplained, is of practical significance in the management of patients with this disease.

\section{Material and Methods}

Patients.-Twenty patients with SLE and 23 with definite or classical rheumatoid arthritis were obtained from the Connective Tissue Disease and Arthritis Clinics and the in-patient medical service of the Johns Hopkins Hospital. Selection was based solely upon certainty of clinical diagnosis and the patients' cooperation and availability for study. All were women.

112 controls were obtained from among female patients hospitalized on the medical service. Specifically excluded from the control group were patients with definite or suspect connective tissue disease, patients with tuberculosis, and potentially anergic individuals such as those with sarcoidosis, Hodgkin's disease, or patients receiving cytotoxic drug therapy.

Skin Test Procedure.-Patients were tested with the following battery of six antigens:

(1) Intermediate strength $\mathrm{PPD}, * 0.0001 \mathrm{mg}$. per $0 \cdot 1 \mathrm{ml}$;

(2) Histoplasmin, ${ }^{*}$ 1:100 dilution;

(3) Trichophytin, ** 1:30 dilution;

(4) Candida albicans extract, ${ }^{* *} 1: 100$ dilution;

(5) Streptokinase (SK)-Streptodornase (SD), *** 10 units SK and 2.5 units SD per $0.1 \mathrm{ml}$;

(6) Calf thymus DNA, ${ }^{* * * *} 0.1 \mathrm{mg}$. per $0.1 \mathrm{ml}$., after the method of Ores and Lange (1964).

* Parke, Davis \& Co.

**Hollister-Stier Laboratories.

***Lederle Laboratories, as "Varidase".

****Mann Research Laboratories. 
$0.1 \mathrm{ml}$. of each antigen was injected intradermally in the volar surface of the forearm. All tests were performed simultaneously in each patient. Reactions were read at 24 and 48 hours by two observers, and millimetres of erythema and induration were recorded. The test was considered positive only when five millimetres or more of induration were present at one or both of these times.

Serum Factors.-Immediately before skin testing, venous blood was obtained from all patients and controls, for subsequent determination of antinuclear factor activity. The immunofluorescent technique of Holborow and Johnson (1964) was used, with rat liver sections as the source of antigen. The test was considered positive when nuclear fluorescence was demonstrated at a serum dilution of 1:10 or greater. In addition, L.E.-cell tests were performed on all patients with SLE by the method of Zinkham and Conley (1956).

Clinical Data.-After skin test results had been recorded, a medical summary was prepared on each patient, with emphasis on exposure history, features of past and current illness suggesting immunological disorders, and drug therapy. Clinical analyses were performed without knowledge of reactivity to DNA. Statements of statistical significance are based on $\chi^{2}$ analysis using Yates' correction.

\section{Results}

As shown in Table $I$, the patients, all women, were predominantly Negroes in the fourth, fifth, and sixth decades of life. Patients with SLE formed a significantly younger group, with an average age of 38 years, as compared to a mean age of 51 for those

TABLE I

AGE, SEX AND RACE OF PATIENTS (all females)

\begin{tabular}{|c|c|c|c|c|}
\hline \multicolumn{2}{|c|}{ Clinical Diagnosis } & SLE & RA & Controls \\
\hline \multirow[b]{2}{*}{ Race } & Total & 20 & 23 & 112 \\
\hline & $\begin{array}{l}\text { Negro } \\
\text { White }\end{array}$ & $\begin{array}{r}11 \\
9\end{array}$ & $\begin{array}{l}10 \\
13\end{array}$ & $\begin{array}{l}87 \\
25\end{array}$ \\
\hline Age (yrs) & $\begin{array}{l}\text { Less than } 20 \\
20-29 \\
30-39 \\
40-49 \\
50-59 \\
60-69 \\
70-79\end{array}$ & $\begin{array}{l}2 \\
6 \\
3 \\
3 \\
5 \\
1 \\
-.\end{array}$ & $\begin{array}{l}- \\
3 \\
1 \\
5 \\
7 \\
6 \\
1\end{array}$ & $\begin{array}{r}3 \\
16 \\
21 \\
20 \\
19 \\
18 \\
15\end{array}$ \\
\hline
\end{tabular}

with rheumatoid arthritis and of 48 years for the controls.

Frequency of Positive Tests (Table II).-No difference was found among patients with SLE, rheumatoid arthritis, and controls with respect to the frequency of positive reactors to trichophytin, Candida albicans extract, streptokinase-streptodornase, or histoplasmin.

None of the twenty patients with SLE, however, showed a positive response to intermediate strength PPD, while approximately one-quarter of the patients with rheumatoid arthritis and one-third of the controls had positive tests. This significant lack of reactivity to tuberculin could not be explained on the basis of exposure history to tuberculosis. Six (30 per cent.) of those with SLE had a known exposure to the disease, as did five ( 22 per cent.) patients with rheumatoid arthritis and sixteen (14 per cent.) controls. On the other hand, only two of these five rheumatoid arthritis patients and four of the sixteen controls with exposure to tuberculosis had positive intradermal tests, indicating overall poor correlation between reactivity and epidemiologic data.

Reactivity to DNA was surprisingly low (20 per cent.) in patients with SLE, occurring no more frequently in this group than in those with rheumatoid arthritis ( 22 per cent.) or controls (18 per cent.).

Frequency of Multiple Positive Tests.-The number of positive tests per patient was no greater for those with systemic lupus. Only six ( 30 per cent.) of the SLE patients reacted to three antigens; none reacted to more than three. In contrast, twelve (52 per cent.) of those with rheumatoid arthritis and 59 ( 53 per cent.) of the controls had three or more positive tests to the five bacterial and fungal antigens.

Intensity of Response.-With no increase in the frequency of positive reactors to any of the administered antigens and no greater number of multiple

TABLE II

FREQUENCY OF POSITIVE REACTORS

\begin{tabular}{|c|c|c|c|c|c|c|c|c|c|c|c|c|c|}
\hline \multirow{3}{*}{$\begin{array}{c}\text { Clinical } \\
\text { Diagnosis }\end{array}$} & \multirow{3}{*}{$\begin{array}{c}\text { Total } \\
\text { Number } \\
\text { of } \\
\text { Patients }\end{array}$} & \multicolumn{12}{|c|}{ Positive Reactors } \\
\hline & & \multicolumn{2}{|c|}{ PPD* } & \multicolumn{2}{|c|}{ Histoplasmin } & \multicolumn{2}{|c|}{ Trichophytin } & \multicolumn{2}{|c|}{ Candida albicans } & \multicolumn{2}{|c|}{ SK-SD* } & \multicolumn{2}{|c|}{ DNA* } \\
\hline & & No. & Per cent. & No. & Per cent. & No. & Per cent. & No. & Per cent. & No. & Per cent. & No. & Per cent. \\
\hline $\begin{array}{l}\text { SLE } \\
\text { RA } \\
\text { Controls }\end{array}$ & $\begin{array}{r}20 \\
23 \\
112\end{array}$ & $\begin{array}{r}0 \\
6 \\
37\end{array}$ & $\begin{array}{r}0 \\
26 \\
33\end{array}$ & $\begin{array}{r}1 \\
4 \\
17\end{array}$ & $\begin{array}{r}5 \\
17 \\
15\end{array}$ & $\begin{array}{r}19 \\
22 \\
106\end{array}$ & $\begin{array}{l}95 \\
96 \\
95\end{array}$ & $\begin{array}{l}14 \\
19 \\
78\end{array}$ & $\begin{array}{l}70 \\
83 \\
70\end{array}$ & $\begin{array}{r}7 \\
8 \\
43\end{array}$ & $\begin{array}{l}35 \\
35 \\
38\end{array}$ & $\begin{array}{r}4 \\
5 \\
20\end{array}$ & $\begin{array}{l}20 \\
22 \\
18\end{array}$ \\
\hline
\end{tabular}


test reactors among those with SLE, the possibility still remained that the intensity of the response was greater in this group. Shown in Table III are the average millimetres of induration in patients with positive tests. No significant difference in mean response to any antigen was observed among the clinical groups. Moreover, the intensity of the reaction to DNA was uniformly less than the response to the bacterial and fungal antigens.

TABLE III

INTENSITY OF POSITIVE REACTIONS

\begin{tabular}{l|c|c|c|c|c|c}
\hline \multirow{2}{*}{$\begin{array}{c}\text { Clinical } \\
\text { Diagnosis }\end{array}$} & \multicolumn{6}{|c|}{ Mean Positive Response (mm.) } \\
\cline { 2 - 6 } & PPD* $^{*}$ & $\begin{array}{c}\text { Histo- } \\
\text { plasmin }\end{array}$ & $\begin{array}{c}\text { Tricho- } \\
\text { phytin }\end{array}$ & $\begin{array}{c}\text { Candida } \\
\text { albicans }\end{array}$ & SK-SD* & DNA* \\
\hline SLE & - & $10 \dagger$ & 17 & 18 & 13 & 6 \\
RA & $\begin{array}{c}10 \\
\text { Controls }\end{array}$ & $\mathbf{8}$ & 11 & 13 & 12 & 6 \\
\hline
\end{tabular}

*See text

†Denotes single positive test

Clinical Features of SLE and Cutaneous Reactivity (Table IV).-Patients with SLE ranged from 17 to 68 years of age, eleven of whom were Negro and nine Caucasian. On clinical grounds alone, the disease was considered active in eleven, as manifested by objective signs of inflammation in one or more tissue sites. Polyarthritis, active skin lesions, and serositis were the dominant manifestations. Three with active disease and five with disease in remission or suppression by therapy had biopsy-proven nephritis. At the time of this study, a positive test for antinuclear factors was found in fifteen patients; the L.E.-cell test was positive in twelve. (However, nineteen of the twenty patients had had antinuclear factors detected earlier in their course, and L.E.-cells had been found previously in seventeen.) Seven patients with SLE had never received corticosteroid therapy; in an additional patient, prednisone had been discontinued over 5 years earlier. Only two were receiving prednisone in excess of $25 \mathrm{mg}$. daily.

Cutaneous reactivity could not be correlated with any specific clinical or serologic feature of the disease. Of the four patients with positive skin tests to DNA, only one had active disease. Nephritis was present in three of the four, but five patients with nephritis showed no reaction to intradermal DNA.

Three factors, independent of the diagnosis of SLE, remained to be evaluated in relation to cutaneous reactivity, namely, (1) circulating antinuclear antibody, (2) corticosteroid therapy, and (3) age.

Serum Antinuclear Factors (ANF).-No positive correlation could be found between the presence of antinuclear factors in serum and the response to intradermal DNA (Table V). Of the four SLE

TABLE V

RELATIONSHIP OF DNA SKIN TESTS REACTIVITY TO SERUM ANTINUCLEAR FACTORS (ANF)

\begin{tabular}{|c|c|c|c|c|}
\hline \multirow{2}{*}{\multicolumn{2}{|c|}{$\begin{array}{c}\text { Clinical } \\
\text { Diagnosis }\end{array}$}} & \multirow{3}{*}{$\begin{array}{c}\begin{array}{c}\text { Total } \\
\text { Number of } \\
\text { Patients }\end{array} \\
4 \\
16\end{array}$} & \multicolumn{2}{|c|}{ Number of Patients } \\
\hline & & & \multirow{2}{*}{$\frac{A N F+}{2}$} & \multirow{2}{*}{$\begin{array}{c}\text { ANF - } \\
2 \\
4\end{array}$} \\
\hline SLE & $\begin{array}{l}\text { DNA + } \\
\text { DNA - }\end{array}$ & & & \\
\hline RA & $\begin{array}{l}\text { DNA + } \\
\text { DNA - }\end{array}$ & $\begin{array}{r}5 \\
18\end{array}$ & $\begin{array}{l}1 \\
3\end{array}$ & $\begin{array}{r}4 \\
15\end{array}$ \\
\hline Controls & $\begin{array}{l}\text { DNA + } \\
\text { DNA - }\end{array}$ & $\begin{array}{l}20 \\
92\end{array}$ & - & $\begin{array}{l}20 \\
92\end{array}$ \\
\hline
\end{tabular}

TABLE IV

CLINICAL AND SEROLOGICAL FEATURES AND SKIN TEST REACTIVITY IN PATIENTS WITH SLE

\begin{tabular}{|c|c|c|c|c|c|c|c|c|c|c|c|c|c|}
\hline \multirow{2}{*}{$\begin{array}{c}\text { Patient } \\
\text { No. }\end{array}$} & \multirow{2}{*}{$\begin{array}{c}\text { Age } \\
\text { (yrs) }\end{array}$} & \multirow{2}{*}{ Race* } & \multirow{2}{*}{$\begin{array}{l}\text { Activity } \\
\text { of SLE }\end{array}$} & \multirow{2}{*}{ Nephritis } & \multirow{2}{*}{$\begin{array}{c}\text { Anti- } \\
\text { nuclear } \\
\text { Factor }\end{array}$} & \multirow{2}{*}{$\begin{array}{l}\text { L.E.- } \\
\text { Cells }\end{array}$} & \multirow{2}{*}{$\begin{array}{l}\text { Prednisone } \\
\text { (mg. q.d.) }\end{array}$} & \multicolumn{6}{|c|}{ Skin Test Reactivity } \\
\hline & & & & & & & & PPD & $\begin{array}{c}\text { Histo- } \\
\text { plasmin }\end{array}$ & $\begin{array}{l}\text { Tricho- } \\
\text { phytin }\end{array}$ & $\begin{array}{l}\text { Candida } \\
\text { albicans }\end{array}$ & SK-SD & DNA \\
\hline $\begin{array}{r}1 \\
2 \\
3 \\
4 \\
5 \\
6 \\
7 \\
8 \\
9 \\
10 \\
11 \\
12 \\
13 \\
14 \\
15 \\
16 \\
17 \\
18 \\
19 \\
20\end{array}$ & $\begin{array}{l}17 \\
18 \\
22 \\
23 \\
26 \\
26 \\
29 \\
37 \\
38 \\
39 \\
53 \\
21 \\
44 \\
45 \\
48 \\
51 \\
52 \\
53 \\
54 \\
68\end{array}$ & $\begin{array}{l}\mathbf{N} \\
\mathbf{W} \\
\mathbf{N} \\
\mathbf{N} \\
\mathbf{W} \\
\mathbf{W} \\
\mathbf{W} \\
\mathbf{N} \\
\mathbf{N} \\
\mathbf{N} \\
\mathbf{N} \\
\mathbf{N} \\
\mathbf{N} \\
\mathbf{W} \\
\mathbf{N} \\
\mathbf{W} \\
\mathbf{W} \\
\mathbf{N} \\
\mathbf{W} \\
\mathbf{W}\end{array}$ & $\begin{array}{l}+ \\
+ \\
+ \\
+ \\
+ \\
+ \\
+ \\
+ \\
+ \\
+ \\
\pm \\
= \\
= \\
= \\
= \\
= \\
-\end{array}$ & $\begin{array}{l}\bar{z} \\
+ \\
\pm \\
\bar{y} \\
\overline{-} \\
\overline{-} \\
\overline{+} \\
+ \\
+ \\
\pm \\
\overline{+} \\
\overline{+} \\
\pm \\
-\end{array}$ & $\begin{array}{l}+ \\
+ \\
+ \\
+ \\
+ \\
+ \\
+ \\
+ \\
+ \\
+ \\
+ \\
+ \\
+ \\
+ \\
+ \\
+ \\
+\end{array}$ & $\begin{array}{l} \pm \\
+ \\
\pm \\
+ \\
+ \\
+ \\
\pm \\
+ \\
\pm \\
+ \\
\pm \\
+ \\
\pm \\
+ \\
+\end{array}$ & $\begin{array}{r}25 \\
0 \\
20 \\
45 \\
0 \\
0 \\
10 \\
0 \\
0 \\
0 \\
0 \\
20 \\
20 \\
10 \\
0 \\
7 \cdot 5 \\
20 \\
5 \\
5 \\
35\end{array}$ & $\begin{array}{l}\bar{z} \\
\bar{z} \\
\bar{z} \\
\bar{z} \\
\overline{-} \\
\bar{z} \\
\bar{z} \\
\bar{z} \\
\overline{-} \\
\overline{-} \\
\overline{-}\end{array}$ & $\begin{array}{l}\overline{-} \\
\bar{z} \\
\bar{z} \\
\overline{-} \\
\overline{-} \\
\overline{-} \\
\overline{+} \\
\overline{-} \\
\overline{-} \\
\overline{-} \\
\overline{-}\end{array}$ & $\begin{array}{l}+ \\
+ \\
+ \\
+ \\
+ \\
+ \\
+ \\
+ \\
+ \\
+ \\
+ \\
+ \\
+ \\
+ \\
+ \\
+ \\
+ \\
+ \\
+\end{array}$ & $\begin{array}{l}+ \\
+ \\
+ \\
+ \\
+ \\
+ \\
+ \\
+ \\
+ \\
+ \\
+ \\
+ \\
+ \\
+ \\
+ \\
+ \\
+\end{array}$ & 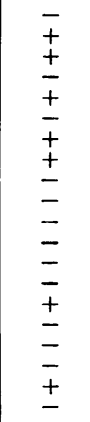 & $\begin{array}{l}\bar{z} \\
\bar{z} \\
\overline{+} \\
\overline{-} \\
\overline{-} \\
\overline{+} \\
\pm \\
\overline{+} \\
\pm \\
\overline{-} \\
\overline{-}\end{array}$ \\
\hline
\end{tabular}


patients with positive skin tests to DNA, two were ANF positive and two were not. Even more striking were the data in the other two clinical groups. Only one of the five patients with rheumatoid arthritis and a positive DNA skin test was ANF positive, and in none of the twenty controls with positive skin tests were serum antinuclear factors demonstrable.

Corticosteroid Therapy.-Twelve patients with SLE, six with rheumatoid arthritis, and sevèn controls were on maintenance cortiçosteroid therapy at the time of skin testing. In only two SLE patients did the dosage level exceed $25 \mathrm{mg}$. prednisone, or its equivalent, per day. There was no evidence that this range of steroid therapy altered cutaneous reactivity to any of the administered antigens, either in terms of the frequency of positive reactors (Table VI) or the intensity of response (Table VII).

The Factor of Age.-Since our clinical groups were not matched with respect to age and thus were not strictly comparable on this factor, consideration was given to the possibility that disease-related differences in host reactivity might be masked by agedependent factors. The control population, ranging from the second through the seventh decade of age, was thus analysed in this regard. Over this age span, the frequency of patients with positive tests (Table VIII, opposite) was remarkably constant for each decade. Similarly, the number of positive tests per patient, as well as the intensity of the cutaneous response (Table IX, opposite), was not significantly influenced by advancing age.

\section{Discussion}

Skin tests with bacterial and fungal antigens represent the conventional means of evaluating the capacity of an individual to manifest delayed hypersensitivity. It is somewhat surprising that this measure of cellular hypersensitivity has not been adequately studied in patients with SLE, especially in view of the recent interest in cutaneous reactivity in these patients to leucocyte and nuclear antigens.

Numerous studies have shown that certain antigens, such as Candida albicans extract and trichophytin, may be considered universal antigens in that they evoke positive responses in the vast majority of healthy adults. As anticipated on epidemiologic grounds, other antigens, as histoplasmin and tuberculin, are more selective. Finally, deoxyribonucleic acid (DNA) has been reported to be highly specific

TABLE VI

RELATIONSHIP OF SKIN TEST REACTIVITY TO CORTICOSTEROID THERAPY

Frequency of Positive Reactors

\begin{tabular}{|c|c|c|c|c|c|c|c|c|}
\hline \multirow{2}{*}{\multicolumn{2}{|c|}{ Clinical Diagnosis }} & \multirow{3}{*}{$\begin{array}{c}\begin{array}{c}\text { Total } \\
\text { Number } \\
\text { of Patients }\end{array} \\
\frac{12}{8}\end{array}$} & \multicolumn{6}{|c|}{ Positive Reactors } \\
\hline & & & PPD* & Histoplasmin & Trichophytin & Candida albicans & SK-SD* & DNA* \\
\hline SLE & $\begin{array}{l}\text { Steroids } \\
\text { No Steroids }\end{array}$ & & - & $\begin{array}{l}1 \\
-\end{array}$ & $\begin{array}{r}12 \\
7\end{array}$ & $\begin{array}{l}7 \\
7\end{array}$ & $\begin{array}{l}3 \\
4\end{array}$ & 3 \\
\hline $\mathbf{R A}$ & $\begin{array}{l}\text { Steroids } \\
\text { No Steroids }\end{array}$ & $\begin{array}{r}6 \\
17\end{array}$ & $\overline{6}$ & 2 & $\begin{array}{r}6 \\
16\end{array}$ & $\begin{array}{r}6 \\
13\end{array}$ & $\begin{array}{l}3 \\
5\end{array}$ & $\overline{5}$ \\
\hline Controls & $\begin{array}{l}\text { Steroids } \\
\text { No Steroids }\end{array}$ & $\begin{array}{r}7 \\
105\end{array}$ & $\begin{array}{r}1 \\
36\end{array}$ & $1 \frac{2}{5}$ & $\begin{array}{r}6 \\
100^{6}\end{array}$ & $\begin{array}{r}6 \\
72\end{array}$ & $\begin{array}{r}1 \\
42\end{array}$ & $\begin{array}{r}1 \\
19\end{array}$ \\
\hline
\end{tabular}

*See text

TABLE VII

RELATIONSHIP OF SKIN TEST REACTIVITY TO CORTICOSTEROID THERAPY

Intensity of Positive Reaction

\begin{tabular}{|c|c|c|c|c|c|c|c|}
\hline \multirow{2}{*}{\multicolumn{2}{|c|}{ Clinical Diagnosis }} & \multicolumn{6}{|c|}{ Mean Positive Response (mm.) } \\
\hline & & PPD* & Histoplasmin & Trichophytin & Candida albicans & SK-SD* & $\mathrm{DNA}^{*}$ \\
\hline SLE & $\begin{array}{l}\text { Steroids } \\
\text { No Steroids }\end{array}$ & - & $10+$ & $\begin{array}{l}19 \\
14 \\
\end{array}$ & $\begin{array}{l}18 \\
17 \\
\end{array}$ & $\begin{array}{l}14 \\
13 \\
\end{array}$ & 7 \\
\hline $\mathbf{R A}$ & $\begin{array}{l}\text { Steroids } \\
\text { No Steroids }\end{array}$ & $\overline{9}$ & $\begin{array}{r}6 \\
10 \\
\end{array}$ & $\begin{array}{l}14 \\
10 \\
\end{array}$ & $\begin{array}{l}12 \\
13 \\
\end{array}$ & $\begin{array}{l}10 \\
13\end{array}$ & $\overline{6}$ \\
\hline Controls & $\begin{array}{l}\text { Steroids } \\
\text { No Steroids }\end{array}$ & ${ }_{9}^{5+}$ & $\begin{array}{l}9 \\
8\end{array}$ & $\begin{array}{l}14 \\
14\end{array}$ & $\begin{array}{l}11 \\
15\end{array}$ & $\begin{array}{c}8 \dagger \\
12\end{array}$ & $\frac{6 t}{7}$ \\
\hline
\end{tabular}


TABLE VIII

RELATIONSHIP OF SKIN TEST REACTIVITY TO AGE IN THE CONTROL POPULATION

Frequency of Positive Reactors

\begin{tabular}{|c|c|c|c|c|c|c|c|c|c|c|c|c|c|}
\hline \multirow{3}{*}{$\begin{array}{c}\text { Age } \\
\text { (yrs) }\end{array}$} & \multirow{3}{*}{$\begin{array}{c}\text { Total } \\
\text { Number } \\
\text { of } \\
\text { Patients }\end{array}$} & \multicolumn{12}{|c|}{ Positive Reactors } \\
\hline & & \multicolumn{2}{|c|}{ PPD* } & \multicolumn{2}{|c|}{ Histoplasmin } & \multicolumn{2}{|c|}{ Trichophytin } & \multicolumn{2}{|c|}{ Candida albicans } & \multicolumn{2}{|c|}{ SK-SD* } & \multicolumn{2}{|c|}{ DNA* } \\
\hline & & No. & Per cent. & No. & Per cent. & No. & Per cent. & No. & Per cent. & No. & Per cent. & No. & Per cent. \\
\hline $\begin{array}{l}\text { Less than } 20 \\
20-29 \\
30-39 \\
40-49 \\
50-59 \\
60-69 \\
70-79\end{array}$ & $\begin{array}{r}3 \\
16 \\
21 \\
20 \\
19 \\
18 \\
15\end{array}$ & $\begin{array}{l}\overline{3} \\
7 \\
9 \\
5 \\
6 \\
7\end{array}$ & $\begin{array}{r}0 \\
19 \\
33 \\
45 \\
26 \\
33 \\
47\end{array}$ & $\begin{array}{l}\overline{1} \\
1 \\
5 \\
3 \\
2 \\
3 \\
3\end{array}$ & $\begin{array}{r}0 \\
6 \\
24 \\
15 \\
11 \\
17 \\
20\end{array}$ & $\begin{array}{r}2 \\
16 \\
20 \\
19 \\
18 \\
17 \\
14\end{array}$ & $\begin{array}{r}67 \\
100 \\
95 \\
95 \\
95 \\
94 \\
94\end{array}$ & $\begin{array}{r}1 \\
12 \\
16 \\
14 \\
13 \\
13 \\
9\end{array}$ & $\begin{array}{l}33 \\
75 \\
76 \\
70 \\
68 \\
61 \\
60\end{array}$ & $\begin{array}{r}-\overline{8} \\
12 \\
7 \\
6 \\
8 \\
2\end{array}$ & $\begin{array}{r}\mathbf{0} \\
\mathbf{5 0} \\
\mathbf{5 7} \\
\mathbf{3 5} \\
\mathbf{3 2} \\
\mathbf{4 4} \\
\mathbf{1 3}\end{array}$ & $\begin{array}{l}\overline{5} \\
5 \\
3 \\
2 \\
4 \\
1\end{array}$ & $\begin{array}{r}0 \\
31 \\
24 \\
15 \\
11 \\
22 \\
7\end{array}$ \\
\hline
\end{tabular}

*See text

TABLE IX

RELATIONSHIP OF SKIN TEST REACTIVITY TO AGE IN CONTROL POPULATION

Intensity of Positive Reaction

\begin{tabular}{l|c|c|c|c|c|c}
\hline \multirow{2}{*}{ Age (yrs) } & \multicolumn{5}{|c|}{ Mean Positive Response (mm.) } \\
\cline { 2 - 6 } & PPD* & $\begin{array}{c}\text { Histo- } \\
\text { plasmin }\end{array}$ & $\begin{array}{c}\text { Tricho- } \\
\text { phytin }\end{array}$ & $\begin{array}{c}\text { Candida } \\
\text { albicans }\end{array}$ & SK-SD* & DNA* \\
\hline Less than 20 & $\overline{7}$ & $\overline{7}$ & 40 & 25 & - & - \\
$20-29$ & 7 & 15 & 13 & 10 & 8 \\
$30-39$ & 8 & 9 & 14 & 18 & 13 & 6 \\
$40-49$ & 9 & 8 & 13 & 15 & 11 & 6 \\
$50-59$ & 12 & 5 & 17 & 15 & 14 & 8 \\
$60-69$ & 9 & 8 & 11 & 13 & 14 & 8 \\
$70-79$ & 9 & 7 & 12 & 12 & 6 & 8 \\
\hline
\end{tabular}

*See text

for SLE. We selected our battery of antigens, therefore, to include this spectrum of reactivity.

Bacterial and Fungal Hypersensitivity.-Patients with SLE did not differ from those with rheumatoid arthritis or the hospitalized control population with respect to frequency of positive reactors to Candida and trichophytin. Moreover, the frequency of positive tests to these antigens in three clinical groups was comparable to that reported by others in healthy individuals (Friou, 1952; Kirkpatrick, Wilson, and Talmage, 1964; Kelly, Good, and Varco, 1958). While there was a tendency for those with systemic lupus to respond more vigorously than the controls and for those with rheumatoid arthritis to have less intensely positive reactions, these quantitative differences were not statistically signifcant. In fact, with respect to bacterial and fungal hypersensitivity, the only significant abnormality was the unexpected anergy to tuberculin (PPD) in those with SLE.

None of the twenty patients with systemic lupus developed a positive response to intermediate strength PPD. In contrast, 37 of the 112 (33 per cent.) controls and six ( 26 per cent.) of those with rheumatoid arthritis had positive tests. The incidence of positive PPD reactions in our rheumatoid and control patients is similar to that found in population surveys of tuberculin (PPD) reactivity in Wilson County, North Carolina (Peck, Wells, Abernathy, and Campbell, 1961), and in Tecumseh, Michigan (Dodge, Payne, Whitehouse, and Bauman, 1965). If one selects from the data of Peck and others (1961) the observations on women over the age of 14 years, 436 of 1,569 women ( 28 per cent.) had positive tests as defined by five or more millimetres of induration. Similarly, Dodge and others (1965) found positive reactions in 56 of the 221 women ( 25 per cent.) over the age of 20 years.

As yet, we have no satisfactory explanation for the observed anergy to PPD in our patients with systemic lupus. Host factors, such as age and race, which are known to influence response to tuberculin, would not appear to differ sufficiently from controls to provide an adequate explanation. Known exposure to tuberculosis was as frequent in those with SLE as among patients with other disorders. None of the patients with systemic lupus was uraemic or otherwise debilitated and none was receiving immunosuppressive levels of corticosteroid therapy. Moreover, the hyporeactivity in SLE patients was selective for PPD which argues strongly against a basic alteration in host capacity to manifest delayed hypersensitivity and suggests the possibility of altered immunity to mycobacteria. Of interest in this regard is the high incidence of tuberculosis found among the patients with systemic lupus reported by Harvey, Shulman, Tumulty, Conley, and Schoenrich (1954) from this hospital. Of their 38 autopsied patients, death was attributable to SLE in 22, one of whom was unexpectedly found at autopsy to have miliary tuberculosis. Moreover, "extensive tuberculosis" was the immediate cause of death in five additional patients, only one of whom have received corticosteroid therapy. Furthermore, subsequent experience in this hospital differs from 
that of Dubois (1966), who regards tuberculosis as "an unusual complication" in patients with SLE. In view of the practical clinical importance, as well as the theoretical implications, of tuberculin anergy in systemic lupus, further studies are in progress to define more clearly responsiveness to mycobacterial antigens.

Hypersensitivity to DNA.-Ores and Lange (1964) first described cutaneous hypersensitivity to intradermal calf-thymus DNA in all nineteen patients with SLE receiving the antigen. None of the 23 control patients demonstrated a positive response, defined by the authors as an area of induration equal in size to the original injection bleb. It was felt by these workers that the response to intradermal DNA offered a highly sensitive and equally specific diagnostic test for SLE. With more rigorous definition of a positive test in subsequent studies (Azoury and others, 1966; Ores and Lange, 1964; Chieregato and Faldarini, 1964; Fardal and Winkelmann, 1965), fewer than half the patients with systemic lupus have been found to have a positive reaction.

Only four (20 per cent.) of our patients with SLE developed five or more millimetres of induration in response to DNA; the maximal response was 10 millimetres, found in one individual. Moreover, the same degree of reactivity with respect to both frequency of positive reactors and intensity of response was present in those with rheumatoid arthritis and in controls. This lack of specificity was also found by Fardal and Winkelmann (1965), who reported positive tests, similarly defined, in 25 of 82 controls ( 32 per cent.), an incidence of positive reactivity which did not differ from that found in those with SLE. The usefulness of DNA skin testing in clinical diagnosis, therefore, would appear limited.

Furthermore, DNA hypersensitivity did not discriminate between SLE patients with respect to the clinical and serological activity of the disease. The data presented here do not confirm the recent observations of Azoury and others (1966), who reported strongly-positive correlations between DNA reactivity in the skin and antinuclear factor activity of the anti-DNA type in serum. Only two of our four patients with systemic lupus and positive DNA skin tests were found to have circulating antinuclear antibodies at the time of skin testing, and in none of the twenty controls who reacted to intradermal DNA were antinuclear factors demonstrable by immunofluorescence.

The cutaneous response to DNA would not appear to reflect local interaction of antigen and circulating antibody but rather a manifestation of delayed-type hypersensitivity. The intensity of the response to this weak antigen was uniformly less than that found with bacterial and fungal antigens, which may explain in part the more short-lived reaction to DNA. With respect to bacterial and fungal hypersensitivity, the more positive the test (i.e. the greater the area of induration), the longer the time required for complete resolution at the reaction site. The evanescence of the DNA skin test and the appearance of maximal induration at 24 rather than at 48 or 72 hours has suggested the possibility that it represented a departure from classical delayed hypersensitivity. As shown in Table X, the reaction to DNA is not atypical as it might seem. Irrespective of the persistence of the reaction, maximal induration had developed by 24 hours in 33 per cent. of the positive reactors to PPD, in 48 per cent. of those with positive tests to streptokinase-streptodornase, and in more than half of those with positive tests to the fungal antigens. The temporal response to DNA is not unique for this antigen.

TABLE X

TIME OF REACTION FOR POSITIVE TEST

\begin{tabular}{l|c|c|c}
\hline \multicolumn{1}{c|}{ Antigen } & $\begin{array}{c}\text { Total } \\
\text { Number } \\
\text { of } \\
\text { Positive Tests }\end{array}$ & $\begin{array}{c}\text { Positive Tests Maximal } \\
\text { at 24 hours }\end{array}$ \\
\hline DNA* & 29 & No. & Per cent. \\
PPD* & 45 & 27 & 93 \\
Histoplasmin & 22 & 14 & 33 \\
Trichophytin & 147 & 12 & 55 \\
Candida albicans & 111 & 60 & 79 \\
SK-SD* & 58 & 28 & 54 \\
& & & 48 \\
\hline
\end{tabular}

*See text

\section{Summary}

Skin tests with a standard battery of bacterial and fungal antigens and heterologous deoxyribonucleic acid (DNA) have been performed in twenty patients with systemic lupus erythematosus (SLE), 23 patients with rheumatoid arthritis, and 112 hospitalized controls.

No difference was found between the three clinical groups with respect to the frequency and intensity of positive reactions to these antigens, except for significant HYPoreactivity to tuberculin (PPD) in those with SLE.

Only 20 per cent. of patients with SLE manifested positive responses to intradermal calf-thymus DNA, a frequency of positive tests similar to that observed in patients with rheumatoid arthritis (22 per cent.) and in controls (18 per cent.). Moreover, reactivity to DNA in SLE could not be correlated with any clinical or serological feature of the disease. 


\section{REFERENCES}

Azoury, F. J., Jones, H. E., Derbes, V. J., and Gum, O. B. (1966). Ann. intern. Med., 65, 1221 (Intradermal tests and antinuclear factors in systemic lupus erythematosus).

Bennett, J. C., and Holley, H. L. (1961). Arthr. and Rheum., 4, 64 (Intradermal hypersensitivity in systemic lupus erythematosus).

Chieregato, G. C., and Faldarini, G. (1964). Minerva Derm., 39, 108 (Sulle iniezioni intradermiche di autoleucociti e di acidi nucleici nell'eritematode).

Dodge, H. J., Payne, M. W., Whitehouse, W. M., and Bauman, K. A. (1965). Amer. Rev. resp. Dis., 92, 459 (Estimates of the prevalence of tuberculous and histoplasmal injections in a sample population of Tecumseh, Michigan, 1960).

Dubois, E. L. (1966). In "Lupus Erythematosus", ed. E. L. Dubois, p. 403. McGraw Hill, New York: McGraw-Hill (Causes of death in systemic lupus erythematosus).

Fardal, R. W., and Winkelmann, R. K. (1965). Arch. Derm. (Chicago), 91, 503 (Hypersensitivity to deoxyribonucleic acid in cutaneous disease).

Friedman, E. A., Bardawil, W. A., Merrill, J. P., and Hanau, C. (1960). New Engl. J. Med., 262, 486 ("Delayed" cutaneous hypersensitivity to leukocytes in disseminated lupus erythematosus).

Friou, G. J. (1952). Yale J. Biol. Med., 24, 533 (A study of the cutaneous reactions to oidiomycin, trichophytin, and mumps skin test antigens in patients with sarcoidosis).

Harvey, A. M., Shulman, L. E., Tumulty, P. A., Conley, C. L., and Schoenrich, E. H. (1954). Medicine (Baltimore), 33, 291 (Systemic lupus erythematosus: review of the literature and clinical analysis of 138 cases).

Holborow, J., and Johnson, G. D. (1964). Arthr. and Rheum., 7, 119 (Antinuclear factor in systemic lupus erythematosus. A consideration of the immunofluorescent method of detecting antinuclear antibodies, with results obtained in a family study).

Holman, H. (1960). J. Pediat., 56, 109 (Systemic lupus erythematosus. A review of certain recent developments in the study of this disease).

Kelly, W. D., Good, R. A., and Varco, R. L. (1938). Surg. Gynec. Obstet., 107, 565 (Anergy and skin homograft survival in Hodgkin's disease).

Kirkpatrick, C. H., Wilson, W. E. C., and Talmage, D. W. (1964). J. exp. Med., 119, 727 (Immunologic studies in human organ transplantation. I. Observation and characterization of suppressed cutaneous reactivity in uremia).

Ores, R. O., and Lange, K. (1964). Amer. J. med. Sci., 248, 562 (Skin test for the diagnosis of systemic lupus erythematosus).

Peck, W. M., Wells, H. B., Abernathy, J. R., and Campbell, J. A. (1961). Amer. Rev. resp. Dis., 84, 669 (Urban-rural variations in tuberculin sensitivity).

Tromovitch, T. A., and March, C. (1961). J. invest. Derm., 37, 345 (Intradermal tests with autologous white blood cells in chronic discoid lupus erythematosus, systemic lupus erythematosus, and control subjects).

Zinkham, W. H., and Conley, C. L. (1956). Bull. Johns Hopk. Hosp., 98, 102 (Some factors influencing the formation of L.E. cells. A method for enhancing L.E. cell production). 
Hypersensibilitée retardée dans le lupus érythémateux disséminé

RÉSUMÉ

On exécuta toute une série de réactions cutanées avec des antigènes bactériens et mycosiques et avec l'acide désoxyribonucléique (ADN) hétérologue chez vingt malades atteints de lupus érythémateux disséminé (SLE = "systemic lupus erythematosus"), 23 malades atteints de polyarthrite rhumatoïde et chez 112 témoins hospitalisés.

On ne trouva pas de différence entre les trois groupes cliniques en ce qui concerne la fréquence et l'intensité des réactions positives contre ces antigénes, sauf une hyporéactivité significative contre la tuberculine (PPD) chez les malades atteints de SLE.

Seulement 20 pour cent des malades atteints de SLE accusèrent des réactions positives vis-à-vis de l'ADN du thymus de veau intradermique. Ce pourcentage des réactions positives fut similaire à celui obtenu chez les malades atteints de polyarthrite rhumatoïde (22 pour cent) et chez les témoins (18 pour cent). De plus, on ne put établir aucune corrélation entre la réactivité vis-à-vis de l'ADN dans le SLE et tout autre caractère clinique ou sérologique de cette maladie.
Hypersensibilidad tardía en el lupus eritematoso diseminado

SUMARIO

Se ejecutó una serie de reacciones cutáneas con antígenos bacteriales y micóticos y con el ácido deoxiribonucléico (ADN) heterólogo en 20 enfermos con lupus eritematoso diseminado (SLE = "systemic lupus erythematosus"), 23 enfermos con poliartritis reumatoide y en 112 testigos hospitalizados.

No se encontró diferencia alguno entre los tres grupos clínicos respecto a la frecuencia y la intensidad de las reacciones positivas hacia estos antígenos, con la excepción de una hiporeactividad significativa hacia la tuberculina (PPD) en enfermos con SLE.

Sólo un 20 por ciento de los enfermos con SLE acusaron reacciones positivas hacia el ADN del timo de ternero intradérmico. Esta proporción de reacciones positivas fué similar en los enfermos con poliartritis reumatoide ( 22 por ciento) y en los testigos (18 por ciento). Además, no se pudo establecer correlación alguna entre la reactividad hacia el ADN en el SLE y cualquier otro rasgo clínico o serológico de esta enfermedad. 